\title{
Compatibility of Pseudomonas fluorescens with Pesticides in vitro
}

\author{
L.N. Hanuman and G. Bindu Madhavi* \\ Regional Agricultural Research Station, Lam, Guntur, ANGRAU, \\ Andhra Pradesh-522034, India \\ *Corresponding author
}

A B S T R A C T

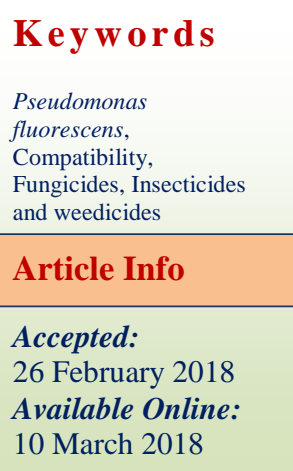

\section{Introduction}

Biological control is an environmentally sound and effective means of reducing or mitigating diseases and disease effects through the use of beneficial microorganisms. Among the bacterial biocontrol agents Pseudomons fluorescens have gained much importance as it is very effective in root colonization and biocontrol activity by producing antifungal metabolites including antibiotics, hydrogen cyanide and siderophores (O'Sullivan and O'Gara, 1992). In recent years, emphasis has been laid on the combined use of biocontrol agents along with chemical pesticides for effective management of pests, diseases and weeds. In the present study, the compatibility of $P$. fluorescens with the 10 insecticides, 6 fungicides and 10 herbicides was done in in vitro

\section{Materials and Methods}

A study on compatibility of effective strain of $P$. fluorescens (PF 16) with fungicides, insecticides and herbicides was conducted during 2014 under laboratory conditions using poison food technique. Three doses of each pesticide viz., $100 \mathrm{ppm}, 500 \mathrm{ppm}$ and 1000 ppm were used for the study. Nutrient agar (NA) plates amended with concentrations of pesticides were prepared by serial dilutions. A 
loopful of active $P$. fluorescens culture was streaked on individual NA plates amended with appropriate concentrations of pesticides and incubated for $48 \mathrm{~h}$. Five replications were maintained for each pesticide and concentration. To measure the compatibility, growth of strain $P$. fluorescens on pesticide amended media was rated as $+++($ Good $) ;+$ + (Moderate); + (Poor); and - (No growth) and compared with growth of $P$. fluorescens on non-amended pesticide NA plates.

\section{Results and Discussion}

\section{Compatibility of Pseudomonas fluorescens with fungicides in vitro}

The results pertaining to compatibility of $P$. fluorescens with six fungicides are presented in Table 1. Strain $P$. fluorescens 16 was compatible with propiconazole, tebuconazole, trifloxistrobin + tebuconazole, azoxystrobin, carbendazim and carbendazim + mancozeb based on its growth and rated as good at 100 ppm concentration.

The strain was moderately compatible to propiconazole, tebuconazole, trifloxystrobin + tebuconazole and carbendazim at $500 \mathrm{ppm}$ concentration and highly compatible with azoxystrobin and carbendazim + mancozeb and did not show any deleterious effect on the growth of P. fluorescens (Plate 1). The strain was poorly compatible with propiconazole, tebuconazole, trifloxistrobin + tebuconazole and carbedazim at $1000 \mathrm{ppm}$ by showing poor growth but showed good compatibility with azoxystrobin.

The results of present study are in accordance with the earlier research reports. Among the bacteria, $P$. fluorescens was found to be more compatible with fungicides than $B$. subtilis and the maximum tolerance concentration for the former being $1600 \mu \mathrm{g}$ mancozeb $/ \mathrm{ml}$, and $50,000 \mu \mathrm{g} / \mathrm{ml}$ for captan and carbendazim
(Mohiddin and Khan 2013). The biocontrol bacteria viz., Pseudomonas fluorescens and Bacillus subtilis were found more tolerant to fungicides than fungi. This may be due to the reason that, some bacteria can use pesticides as nutrients and hence can tolerate higher concentrations of chemicals (Kishore and Jacob, 1987; Aislabie and Jones, 1995). The results of present investigation are in conformity with the compatibility studies of Ahila Devi and Prakasam (2013) and Anand et al., (2009) as Pseudomonas fluorescens and B. subtilis were compatible with azoxystrobin 25 $\mathrm{SC}$ at 5, 10, 50, 100, $250 \mathrm{ppm}$ and $300 \mathrm{ppm}$ concentration. Kataria et al., (2002) reported that lower rates of azoxystrobin in combination with $P$. fluorescens strain 36 resulted in better antagonist interactions against Rhizoctonia solani Kuhn. Sendhil Vel et al., (2004) found that the growths of Pf1 and Bacillus subtilis were not affected by azoxystrobin even at high concentrations.

\section{Compatibility with insecticides}

The results pertaining to compatibility of $P$. fluorescens with insecticides are presented in Table 2. Strain P. fluorescenswas compatible with all the tested insecticides viz., imidacloprid, monocrotophos, chlorpyriphos, trizophos, diafenthiuran, sulphur, spinosad, fipronil, acephate, acetamiprid at all the three concentrations.

Mathew (2003) studied the compatibility of $P$. fluorescens with nine pesticides and found that mancozeb, carbendazim, chlorpyriphos and imidacloprid were highly compatible with $P$. fluorescens strain P11 at there commended dose for field use. Another study on the compatibility of diafenthiuron with antagonistic microorganisms of plant pathogens viz., Trichoderma viride and Pseudomonas fluorescens revealed that diafenthiuron had some inhibitory effect on the mycelial growth of $T$. viride. 


\section{List of pesticides used for compatibility studies}

\begin{tabular}{|c|c|}
\hline S. No. & Pesticide \\
\hline & Fungicides \\
\hline 1. & Propiconazole250 EC \\
\hline 2. & Tebuconazole 430SC \\
\hline 3. & Trifloxystrobin25\%W/W + tebuconazole 50\%W/W, $75 \mathrm{WG}$ \\
\hline 4. & Azoxystrobin 250SC \\
\hline 5. & Carbendazim 50\%DF \\
\hline \multirow[t]{2}{*}{6.} & Carbendazim $12 \%+$ mancozeb $63 \% \mathrm{WP}$ \\
\hline & Insecticides \\
\hline 7. & Imidacloprid70 WG 70\%@.025g \\
\hline 8. & Monocrotophos 36\%SL @ 1.6 ml/1 \\
\hline 9. & Chlorpyriphos 20\%EC @2.5ml/1 \\
\hline 10. & Trizophos 40\%EC @ 1.25 ml/1 \\
\hline 11. & Spinosad $45 \%$ EC $0.25 \mathrm{ml} / 1$ \\
\hline 12. & Diafenthiuran 50\%WP @ 1.25g/l \\
\hline 13. & Sulphur@3g/l \\
\hline 14. & Fipronil granules@8kg/ac \\
\hline 15. & Acephate@1g/l \\
\hline \multirow[t]{2}{*}{16.} & Acetamiprid@ 0.2g/l \\
\hline & Herbicides \\
\hline 17. & Quizalopop Ethyl 5\% EC \\
\hline 18. & Pyrithiobac Sodium $10 \% \mathrm{EC}$ \\
\hline 19. & Oxyflorofen $3.5 \% \mathrm{EC}$ \\
\hline 20. & Cyhalopop Butyl 10\%EC \\
\hline 21. & Glyphosate + ammonium Sulphate 71SG \\
\hline 22. & Pendimethalin $30 \%$ EC \\
\hline 23. & 2, 4 D Sodium Salt $80 \% W P$ \\
\hline 24. & Imazithaphir 10\% EC \\
\hline 25. & Atrazin 50\%WP \\
\hline 26. & Glyphosate $41 \%$ SL \\
\hline
\end{tabular}

Table.1 Compatibility of Pseudomonas fluorescens isolate with commonly used fungicides

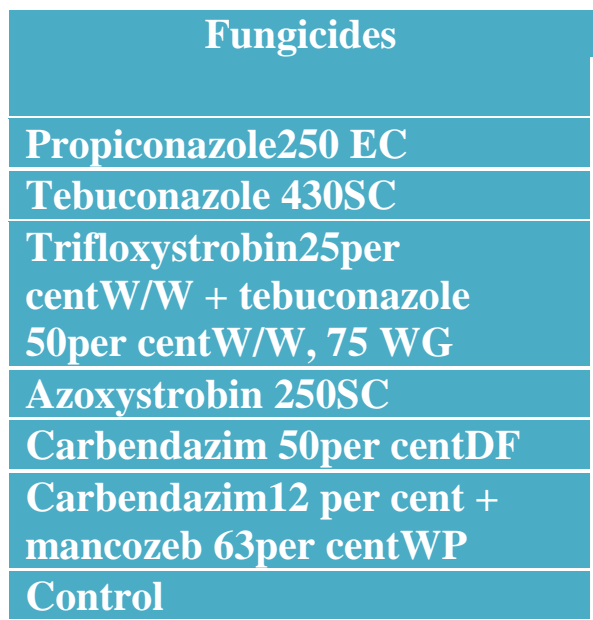

\begin{tabular}{|c|c|c|}
\hline \multicolumn{3}{|c|}{ Growth of Pseudomonas fluorescens 8} \\
\hline $\mathbf{1 0 0} \mathbf{~ p p m}$ & $\mathbf{5 0 0} \mathbf{~ p p m}$ & $\mathbf{1 0 0 0} \mathbf{~ p p m}$ \\
\hline+++ & ++ & + \\
\hline+++ & ++ & + \\
\hline+++ & ++ & + \\
\hline & & \\
\hline+++ & +++ & +++ \\
\hline+++ & ++ & + \\
\hline+++ & +++ & ++ \\
\hline+++ & +++ & +++ \\
\hline
\end{tabular}

${ }^{1}$ Rate of growth of Pseudomonas fluorescens strain 8 in nutrient agar amended with various concentrations of fungicides: $+++=$ Good $++=$ Moderate; $+=$ Poor; and $-=$ No growth . 
Table.2 Compatibility of Pseudomonas fluorescens isolate with commonly used insecticides

\begin{tabular}{|c|c|c|c|}
\hline \multirow[b]{2}{*}{ Insecticide } & \multicolumn{3}{|c|}{ Growth of Pseudomonas fluorescens 8} \\
\hline & 100 ppm & 500 ppm & 1000 ppm \\
\hline T1-Imidacloprid 70 WG 70\%@.025g & +++ & +++ & +++ \\
\hline T2- Monocrotophos 36\% SL @1.6 ml// & +++ & +++ & +++ \\
\hline T3- Chlorpyriphos 20\%EC @2.5ml/1 & +++ & +++ & +++ \\
\hline T4- Triazophos 40\%EC @1.25 ml// & +++ & +++ & +++ \\
\hline T5- Spinosad 45\% EC $0.25 \mathrm{ml} / 1$ & +++ & +++ & +++ \\
\hline T6- Diafenthiuran 50\%WP @ 1.25g/1 & +++ & +++ & +++ \\
\hline T7-Sulphur @3g/l & +++ & +++ & +++ \\
\hline T8- Fipronil granules@8kg/ac & +++ & +++ & +++ \\
\hline T9-Acephate@1g/1 & +++ & +++ & +++ \\
\hline T10-Acetamiprid@ 0.2g/1 & +++ & +++ & +++ \\
\hline T11- Control & +++ & +++ & +++ \\
\hline
\end{tabular}

${ }^{1}$ Rate of growth of Pseudomonas fluorescens strain 8 in nutrient agar amended with various concentrations of fungicides: $+++=$ Good $++=$ Moderate; $+=$ Poor; and $-=$ No growth .

Table.3 Compatibility of Pseudomonas fluorescens isolate with commonly used Herbicides

\begin{tabular}{|l|c|c|c|}
\hline \multicolumn{1}{|c|}{ Herbicide } & \multicolumn{2}{c|}{ Growth of Pseudomonas fluorescens 8} \\
\hline T1- Quivalopop Ethyl 5 \% EC & $\mathbf{1 0 0} \mathbf{~ p p m}$ & $\mathbf{5 0 0} \mathbf{~ p m}$ & $\mathbf{1 0 0 0} \mathbf{~ p m}$ \\
\hline T2- Pyrithiobac Sodium 10 \% EC & +++ & +++ & +++ \\
\hline T3- Oxyflorofen 3.5 \% EC & +++ & +++ & +++ \\
\hline T4- Cyhalopop Butyl 10\% EC & +++ & +++ & +++ \\
\hline T5- Glyphosate + ammonium & +++ & +++ & +++ \\
\hline Sulphate 71SG & +++ & +++ & +++ \\
\hline T6- Pendimethalin 30\% EC & & & \\
\hline T7- 2, 4 D Sodium Salt 80 \% WP & +++ & +++ & +++ \\
\hline T8- Imazithaphir 10\% EC & +++ & +++ & +++ \\
\hline T9- A travin 50 \% WP & +++ & +++ & +++ \\
\hline T10- Glyphosate 41\% SL & +++ & +++ & +++ \\
\hline T11- Control & +++ & +++ & +++ \\
\hline
\end{tabular}

${ }^{1}$ Rate of growth of Pseudomonas fluorescens strain 8 in nutrient agar amended with various concentrations of fungicides: $+++=$ Good; $++=$ Moderate; $+=$ Poor; and $-=$ No growth . 
Plate.1 Compatibility of Pseudomonas fluorescens with different fungicides at 1000ppm
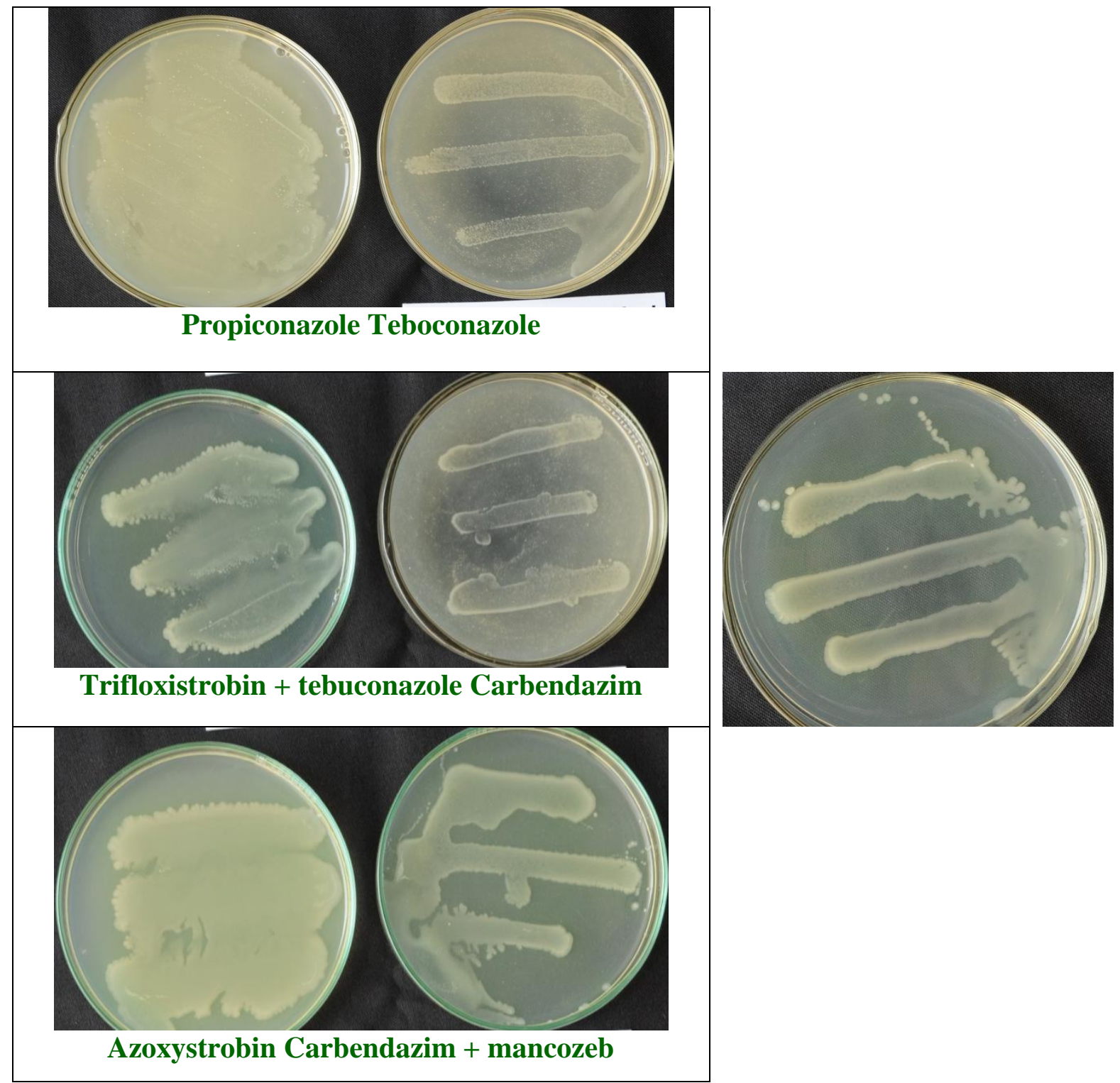

Diafenthiuron did not affect thegrowth of $P$. fluorescens and thus can be used simultaneously for the control of insect pests and seed and soil borne diseases of cardamom.

\section{Compatibility with herbicides}

The results pertaining to compatibility of $P$. fluorescens with herbicicides are presented in Table 3 and found that the strain $P$. fluorescens was compatible with all the tested herbicides viz., quizalopop ethyl, pyrithiobac sodium, oxyflorofen, cyhalopop butyl, glyphosate + ammonium, sulphate, pendimethalin, 2, 4- D sodium salt, imazithaphir, atrazin and glyphosate at all the three concentrations.

Surendran et al., 2012 reported that $P$. fluorescens (PF 43) is highly compatible with 2,4 D sodium salt, metsulfuron methyl $10 \%+$ chlorimuron ethyl $10 \% \mathrm{Wp}$, cyhalopop butyl 10 EC, pyrazosulfuron ethyl 10WP, pretilachlor \%) EC, penoxsulam 24 SP, bispyribac sodium 10SC. Beethi and Pillai (2008) reported that compatibility of $P$. 
fluorescens was questionable with pretilachlor while, it showed compatibility with 2,4 D sodium salt. A combination of biocontrol agents with chemicals will have an additive effect and results in enhanced disease control compared to their individual application (Guetsky et al., 2002). This is necessary to find out the possibility of its utilization in integrated disease management. The present investigation indicated that most of fungicides, insecticides and herbicides tested were compatible with $P$. fluorescens and it could be recommended to the farmers.

\section{References}

Ahila Devi, P and Prakasam, V. 2013. Compatibility nature of azoxystrobin 25 SC with Pseudomonas fluorescens and Bacillus subtilis on chilli plants. World Journal of Agricultural Sciences. 1(8): 258-264.

Aislabie, J and Jones, L.G. 1995. A review of bacterial degradation of pesticides. Australian Journal of Soil Research. 33:925-942.

Anand T., Chandrasekaran, A., Kuttalam, S., Raguchander, $\mathrm{T}$ and Samiyappan, $\mathrm{R}$. 2009. Management of Cucumber (Cucumis sativus L.) mildews through azoxystrobin tolerant Pseudomonas fluorescens. Journal of Agriculture Science and Technology. 11: 211-226.

Beethi B, Pillai RMV. 2008. Compatibility studies of plant growth promoting rhizobacteria with agricultural chemicals. Proceedings of the 20th Kerala Science Congress, 28-31 January 2008, Trivandrum: 190-192.

Guetsky R, Stienberg D, Elad Y, Fischer E, Dinoor A. 2002. Improving biological control by combining biocontrol agents each with several mechanisms of disease suppression. Phytopathology 92: 976-985.

Kataria, H. R., Wilmsmeier, B and Buchenauer, H. 2002. Efficacy of Pseudomanas fluorescens strains and some modern fungicides for control of Rhizoctonia solani AG-4 in bean and cucumber. Journal of Plant Disease Protection. 109: 384-400.

Kishore, G.M and Jacob, G.S. 1987. Degradation of glyphosate by Pseudomonas sp. PG2982 via a sarcosine intermediate. Journal of Biological Chemistry. 262: 12164-1216

Mathew AV. 2003. Pseudomonas fluorescens - Antagonism, compatibility with pesticides and alternate media for mass multiplication. Proceedings of the 6th International PGPR workshop, 5-10 October, 2003, Indian Institute of Spices Research, Calicut, India: 159-164.

Mohiddin, F. A and Khan, M. R. 2013. Tolerance of fungal and bacterial biocontrol agents to six pesticides commonly used in the control of soil borne plant pathogens. African Journal of Agricultural Research. 8 (43):53315334.

O’Sullivan DJ, O'Gara F. 1992. Traits of fluorescent Pseudomonas spp. involved in suppression of plant root pathogens. Microbiology Review 56: 662-676.

SendhilVel, V., Marimuthu, T and Raguchander, T. 2004. Compatibility of Azoxystrobin 25 SC with biocontrol agents. Pestology. 28: 61-64.

Surendran, M., Kannan G. S., Kamala Nayar and Leenakumary, S. 2012. Compatibility of Pseudomonas fluorescens with agricultural chemicals. Journal of Biological Control, 26 (2): 190-193.

\section{How to cite this article:}

Hanuman, L.N. and Bindu Madhavi, G. 2018. Compatibility of Pseudomonas fluorescens with Pesticides in vitro. Int.J.Curr.Microbiol.App.Sci. 7(03): 3310-3315. doi: https://doi.org/10.20546/ijcmas.2018.703.381 